\title{
An Examination of Sustainable Management of Pacific Bluefin Tuna Stock
}

\author{
Takashi Sekiyama \\ Center for Global Education, Toyo University, Tokyo, Japan \\ Email: sekiyama@toyo.jp
}

How to cite this paper: Sekiyama, T. (2017) An Examination of Sustainable Management of Pacific Bluefin Tuna Stock. Journal of Environmental Protection, 8, 26-33. http://dx.doi.org/10.4236/jep.2017.81003

Received: December 27, 2016

Accepted: January 8, 2017

Published: January 11, 2017

Copyright (C) 2017 by author and Scientific Research Publishing Inc. This work is licensed under the Creative Commons Attribution International License (CC BY 4.0).

http://creativecommons.org/licenses/by/4.0/

\section{(c) (†) Open Access}

\begin{abstract}
This paper addresses a fundamental question in conservation ecology, which is the balance between rebuilding of a species' population and exploiting them, by examining an appropriate sustainable management regulation for Pacific Bluefin tuna. The population of Pacific Bluefin tuna has been heavily depleted to just $2.6 \%$ of its historic unfished size by many years of overfishing. In order to rebuild the population, an immediate implementation of a moratorium on all commercial fishing was proposed by NGOs such as the Pew Charitable Trusts and Greenpeace. The primary objective of this paper is to examine the necessity of the moratorium as a sustainable stock management regulation. The paper concludes that an additional $10 \%$ reduction in catch limit of fish less than $30 \mathrm{~kg}$ could be a better alternative management regulation than a total ban on all fishing. This option can increase the probability of the stock recovery, while allowing to catch as many large fishes as under the current management regulation. Through the examination of sustainable stock management for Pacific Bluefin tuna, it can be said that it is important to consider the balance between the recovery of the population and utilization of them. Since millions of people rely on the consumption of the species, it is more realistic to gradually rebuild the population with an intermediate target and an efficient additional catch limit. This consideration can be applied to conservation of other species such as whales and eels.
\end{abstract}

\section{Keywords}

Conservation Ecology, Pacific Bluefin Tuna, Moratorium, Maximum Sustainable Use

\section{Introduction}

The initial purpose of this paper is to examine the necessity of a moratorium on all commercial fishing as sustainable stock management of Pacific Bluefin tuna 
(Thunnus orientalis). Pacific Bluefin tuna is a highly migratory species of great economic importance found throughout the North Pacific Ocean. They mature at 3 to 5 years and live for more than 20 years. The latest stock assessment for Pacific Bluefin found that the population has been heavily depleted to just $2.6 \%$ of its historic unfished size by nearly a century of overfishing [1]. In order to end the overfishing, the Pew Charitable Trusts and Greenpeace proposed immediately implementing a moratorium on all commercial fishing for Pacific Bluefin tuna. On the other hand, however, the tuna is an important source of protein for millions of people in the Asia Pacific region. A typical problem in practice of conservation ecology comes up here. How can we resolve the conflicting requirements, namely the rebuilding of Pacific Bluefin tuna population and the consuming them? What are the problems of the current stock management? Is the moratorium the only way to rebuild the population of Pacific Bluefin Tuna? Are there any better stock management plans? This paper addresses these questions from the perspective of maximum sustainable use of Pacific Bluefin Tuna stock by taking advantage of population viability analysis conducted by the International Scientific Committee for Tuna and Tuna-Like Species in the North Pacific Ocean (hereinafter called "ISC").

In the following sections, the paper examines pros and cons of the current management plan, rationales for a moratorium, and the possibility for alternative management regulation. The paper reveals that gradual rebuilding of the population with an additional catch limit is more realistic way as sustainable stock management. The paper concludes with a statement that it is important to consider the balance between the recovery of the stock and exploitation of them rather than a simple calculation of conservation since millions of people rely on the consumption of Pacific Bluefin.

\section{Background}

Until very recently, it was believed that Pacific Bluefin tuna was not in an overfished condition, even though overfishing was occurring [2]. On the other hand, as sushi and sashimi markets developed all over the world in the 1980s, the demand for Bluefin tuna grew dramatically. Fisheries expanded, and fishing pressure increased significantly due to their commercial activities. In particular the catch of age-0 fishes has increased significantly since the early 1990s [1].

ISC, the group responsible for assessing the status of this stock, conducted a full assessment of Pacific Bluefin stock with data from 1952 to 2012 in 2014, and concluded that the stock was experiencing overfishing and in an overfished condition. According to their estimation, the current fishing mortality rate of Pacific Bluefin tuna exceeds all biological reference points commonly used by fishery managers. The 2014 spawning stock biomass (hereinafter called "SSB") of Pacific Bluefin tuna was around 17,000 tons. The ratio of the 2014 SSB to the theoretical unfished SSB (hereinafter called "SSB current, $\mathrm{F}=0$ ") is less than $2.6 \%$. SSB current, $\mathrm{F}=0$ can roughly be defined as the theoretical SSB size without fishing assuming recent levels of recruitment. These estimated results suggest that over- 
fishing is occurring and the stock is overfished, although specific reference points have not been adopted for this stock. Moreover, as Figure 1 shows, the 2014 recruitment (the number of new fish produced) was relatively low, and the average recruitment from 2010 to 2014 may have been below the historical average level. The low recruitment calls to mind a scenario where so many juveniles are now caught that few reach adulthood [1].

\subsection{Pros and Cons of the Current Management}

The stock of Pacific Bluefin tuna is managed by both the Western and Central Pacific Fisheries Commission (hereinafter called "WCPFC") and the InterAmerican Tropical Tuna Commission (hereinafter called "IATTC"). Both WCPFC and IATTC base their Bluefin tuna management and conservation measures by consensus on science proposed by ISC. Currently, WCPFC set the initial goal of rebuilding the SSB of Pacific Bluefin to the historical median (hereinafter called "SSBMED") within 10 years with at least $60 \%$ probability. For this goal, WCPFC members, including the US and Japan, are required to ensure that total fishing effort for Pacific Bluefin tuna shall stay below the 2002-2004 annual average levels. Also, they shall reduce all catches of "small fish" ( $\geq 30 \mathrm{~kg}$ ) to $50 \%$ of the 2002-2004 annual average levels [3].

According to ISC [1], full implementation of the current management regulation can rebuild SSB of Pacific Bluefin to the historical median by 2024 with $69 \%$ probability, even if historically low recruitment from 1980 to 1989 occurs for the next decade. ISC conducted future projection based on an integrated age-structured model fitted to catch, size-composition and catch-per-unit of effort data from 1952 to 2015. The projection results indicate that the initial goal of WCPFC, rebuilding to SSBMED by 2024 with $60 \%$ probability, is reached under all examined scenarios. However, it should be noted that we cannot blindly trust these optimistic projection results, because the projections could include uncertainty of model parameters.

The future projection is based on a model which is composed of estimates of natural mortality, growth, and fecundity as well as observed quantities such as

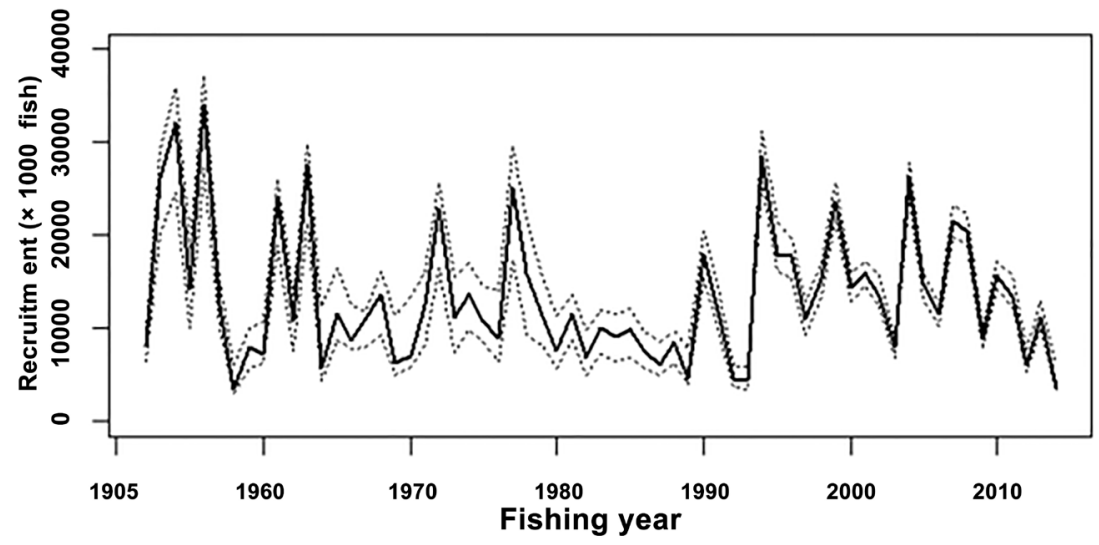

Figure 1. Estimated recruitment of Pacific Bluefin tuna [1]. ${ }^{\star}$ The solid line indicates point estimate and dashed lines indicate the $90 \%$ confidence interval. 
catch and size-composition. Thus, it is inevitable that the projection results sometimes have statistical errors and sampling errors. In fact, ISC's latest assessment estimated the 2014 SSB of Pacific Bluefin as around 17,000 tons, which is about 9000 tons below the 2012 SSB estimated in the 2014. This is not because the SSB suddenly declined from 2012 to 2014, but because of improvements to the input data and refinements to the assessment model which scaled down the estimated value of SSB.

\subsection{Rationales for a Moratorium on All Commercial Fishing}

Although ISC scientists cannot precisely estimate how few spawning Pacific Bluefin tuna would be too few to sustain the population due to the limitation of the projection, the population is likely to be reaching that point. It might be too late when a recruitment decline is evident in the data and there are few juvenile fish to be caught. The earlier catch limits take place, the more quickly the depleted stock can rebuild.

In order to begin the process of rebuilding the population for the future, some NGOs such as The Pew Charitable Trusts and Greenpeace proposed to implement a recovery plan that could rebuild the population to $20 \%$ SSB current, $\mathrm{F}=$ 0 within 8 years (two generations) and then further recover the stock to at least $40 \%$ SSB current, $\mathrm{F}=0$ by 2030 [4]. According to ISC's projection, there is a less than a 1 percent chance that the population will return to $20 \%$ SSBcurrent, $F=0$ by 2034 if commercial fishing continues under the current management and recruitment conditions [1].

Thus, The Pew Charitable Trusts and Greenpeace proposed to immediately implement an initial 2-year moratorium on all commercial fishing for Pacific Bluefin tuna and, if necessary, to extend the moratorium until there is adoption of appropriate recovery planning. Furthermore, they called for an international trade ban if appropriate recovery planning is not in place by 2018 .

\subsection{Repudiation}

Since Pacific Bluefin tuna is an important source of protein for millions of people, it would be necessary to think about this issue from a perspective of sustainable utilization of the stock rather than total ban on all catching. Actually, as the convention clearly states, the principle of WCPFC is also to adopt measures designed to maintain stock levels capable of producing maximum sustainable yield (hereinafter called "MSY") and promote their optimum utilization [5]. MSY is the maximum catch that can be indefinitely taken from the stock, and in theory MSY would be exactly at half the carrying capacity of a species.

From the perspective of maximum sustainable utilization of the stock, it is difficult to say that SSB current, $F=0$ is an appropriate reference point. $20 \%$ SSB current, $\mathrm{F}=0$ is used as the biomass depletion-based limit reference point for other tuna stocks, including skipjack, yellowfin, bigeye, south Pacific albacore and north Pacific albacore. On the other hand, as Figure 2 shows, Pacific Bluefin tuna stock has historically remained below SSB current, $F=0$ for the last 60 


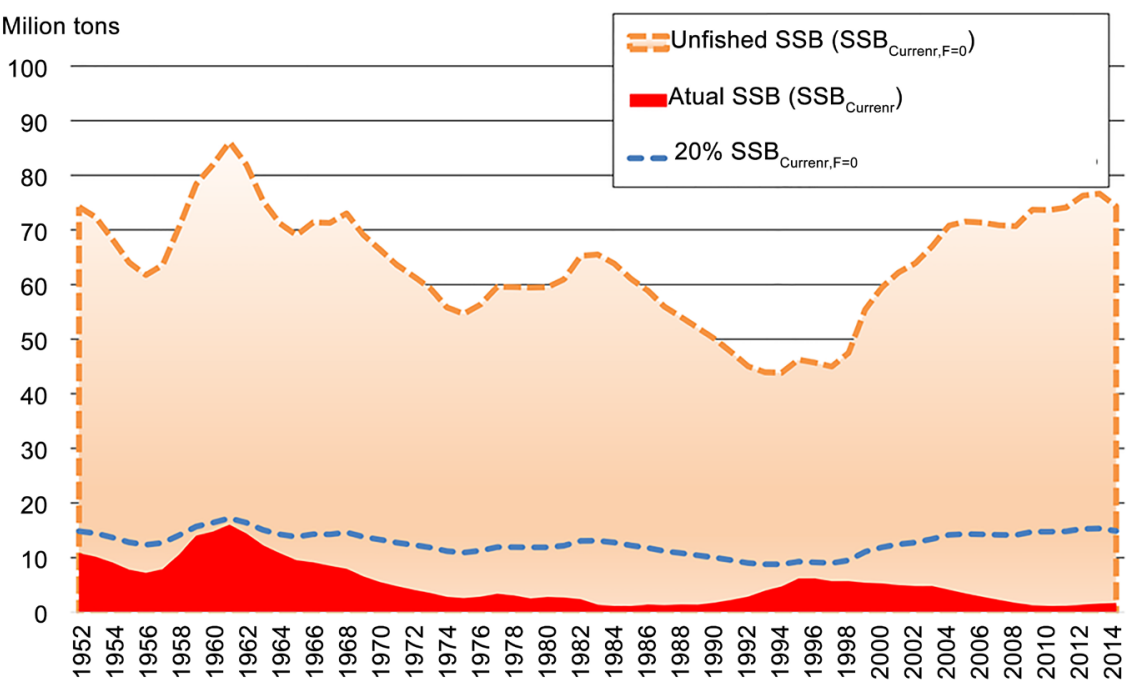

Figure 2. Estimated spawning stock biomass of Pacific Bluefin tuna [6].

years from 1952. Moreover, since SSB current, $\mathrm{F}=0$ is an estimated value as the theoretical SSB size without fishing assuming recent levels of recruitment, the value fluctuates so widely due to changes in the input data and the assessment models that it is not suitable to a reference point in practice.

Also, a smaller number of spawning Bluefin does not necessarily mean that recruitment will be low. Pacific Bluefin tuna are very productive. The females can spawn millions of eggs in one year. Given the many eggs that each mature female can spawn, it is entirely possible to see many juvenile fish while the quantity of spawning fish is still very low [7].

\subsection{Possibility for Alternative Management Regulation}

In light of the balance between the conflicting requirements, namely rebuilding of Pacific Bluefin tuna population and consuming them, it is more realistic to pursue SSBMED as an intermediate goal, rather than unprecedented SSB current, $\mathrm{F}=0$ by implementing a moratorium on all commercial fishing. Unlike widely fluctuating SSB current, F = 0, the value of SSBMED is stable because it is a historical median for several decades. For example, if 1952-2012 is chosen, then SSBMED is estimated to be 41,069 tons, and if 1952-2014 is chosen, SSBMED is 40,994 tons [8]. Nevertheless, as pointed out above, it should be noted that ISC's projections could include uncertainty in estimation of model parameters. Although ISC's projection says that rebuilding to SSBMED by 2024 can be reached under the current management regulation with $69 \%$ probability, this could not be high enough to secure the goal.

According to ISC's projection results, the probability of achieving SSBMED by 2024 would increase if more conservative management measures are implemented. The prospect of recovery is highly dependent on the definition of "small fish" and catch limit. If the definition of "small fish" is changed from the current definition ( $\geq 30 \mathrm{~kg}$ ) to the larger size, it has positive impact on the stock recovery. This is because the impact of fishing on a stock depends on both the number 
and size of the fish caught by each fleet. Catching a high number of smaller juvenile fish can have a greater impact on future SSB than catching the same weight of larger mature fish. Also, an additional reduction in catch limit would provide a higher probability of reaching a higher biomass [1].

Among several scenarios, as shown in Table 1 and Figure 3, it seems to be most efficient to implement an additional $10 \%$ reduction in catch limit of fish less than $30 \mathrm{~kg}$. This option can increase the probability of achieving SSBMED by 2024 to $90 \%$, while allowing to catch as many large fishes as under the current management regulation. This could be a better management regulation than both the current management and the moratorium. Still, it should be noted that the projection's results are based on certain biological and other assumptions. If conditions change, the projection results would be more uncertain.

\section{Conclusions}

In light of the balance between the conflicting requirements, it seems to be more practical to pursue SSBMED as an intermediate goal, rather than unprecedented SSB current, $\mathrm{F}=0$ by implementing a moratorium on all commercial fishing. According to ISC, SSB of Pacific Bluefin can recover to the historical median by

Table 1. Future projection scenarios for Pacific Bluefin tuna [1].

\begin{tabular}{|c|c|c|c|c|}
\hline & $\begin{array}{c}\text { Current } \\
\text { Management } \\
\text { (Scenario 1) }\end{array}$ & $\begin{array}{c}\text { Additional } 10 \% \\
\text { reduction in catch } \\
\text { limit of fish } \geq 30 \mathrm{~kg} \\
(\text { Scenario } 2)\end{array}$ & $\begin{array}{c}\text { Additional } 10 \% \\
\text { reduction in catch } \\
\text { limit of fish <30 kg } \\
(\text { Scenario } 3)\end{array}$ & $\begin{array}{l}\text { Additional } 10 \% \\
\text { reduction in catch } \\
\text { limit of all fish } \\
\text { (Scenario } 4)\end{array}$ \\
\hline $\begin{array}{l}\text { Probability that } \\
\text { SSB is more than } \\
\text { historical median }\end{array}$ & $69.3 \%$ & $90.0 \%$ & $75.3 \%$ & $90.3 \%$ \\
\hline
\end{tabular}

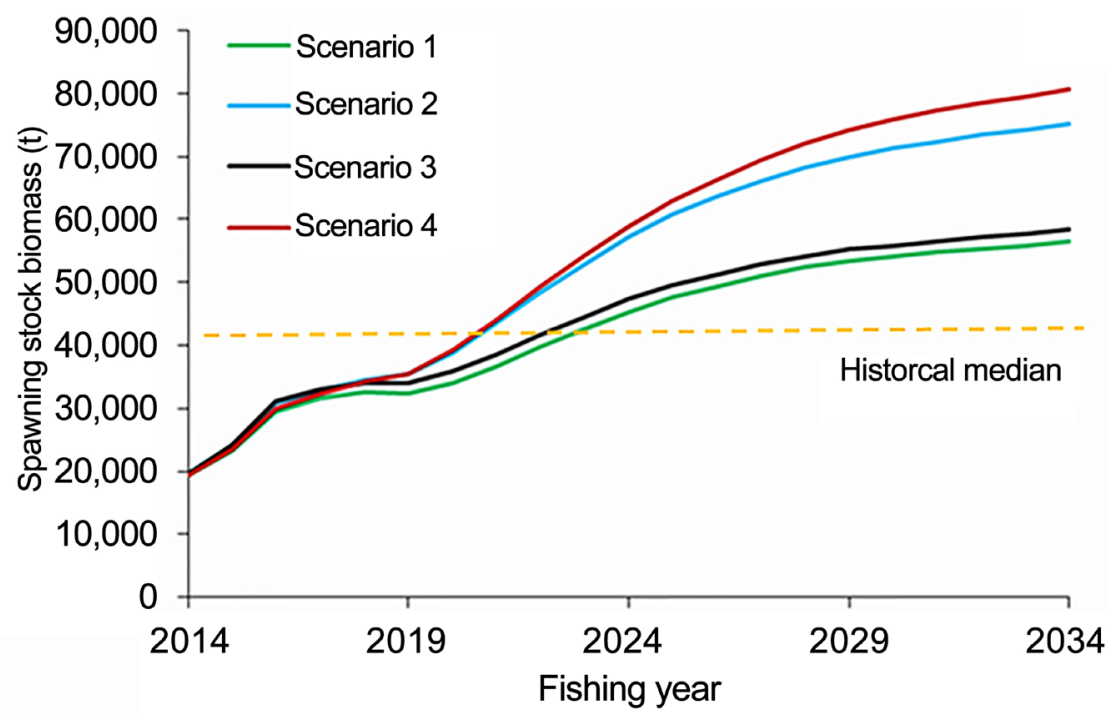

Figure 3. Comparisons of various future projection scenarios [1]. ${ }^{\star}$ The line of historical median was drawn by the author. 
2024 , the initial WCPFC goal, with $69 \%$ probability under the current management regulation. On the other hand, the NGOs called for the moratorium in order to rebuild the population to $20 \%$ of unfished SSB. Pacific Bluefin, however, has yet to achieve this stock level for the last 6 decades. On the other hand, it should be still noted that $69 \%$ probability is not statistically high enough to secure the recovery to SSBMED taking into consideration uncertainties in estimation of model parameters. Thus, an additional $10 \%$ reduction in catch limit of fish less than $30 \mathrm{~kg}$ could be a better alternative management regulation. This option can increase the probability of achieving SSBMED by 2024 to $90 \%$, while allowing to catch as many large fishes as under the current management regulation.

Through the examination of sustainable stock management for Pacific Bluefin tuna, it can be concluded that it is important to consider the balance between the recovery of the population and exploitation of them. Although it is easy to say that a moratorium on catching is necessary to rebuild the population of a species, we should also take into consideration that millions of people rely on the utilization of the species. This conclusion can be applied to conservation of other species, such as whales and eels, of which there are controversies over the sustainable use [9] [10] [11]. The fundamental conflict between the rebuilding and the utilization of a species can be often found in practice of conservation ecology. It is important to be balanced between the conflicting requirements rather than a simple perspective of conservation such as total ban on all catching. Although it is difficult to calculate stock level capable of producing MSY in practice, we should not give up on a stock management which can simultaneously realize sustainability and maximum use of the species.

\section{References}

[1] ISC (2016) Stock Assessment of Pacific Bluefin Tuna 2016. http://isc.fra.go.jp/pdf/ISC16/ISC16_Annex_09_2016\%20Pacific\%20Bluefin\%20Tun a\%20Stock\%20Assessment.pdf

[2] Menashes, E.H. (2011) Fisheries of the Pacific Region; Western Pacific Region. Federal Register, 76, 28422.

https://www.federalregister.gov/articles/2011/05/17/2011-12054/fisheries-of-the-Pac ific-region-western-Pacific-region

[3] WCPFC (2016) Conservation and Management Measures (CMMs) and Resolutions of the Western Central Pacific Fisheries Commission (WCPFC). https://www.wcpfc.int/system/files/booklets/31/CMM\%20and\%20Resolutions.pdf

[4] The Pew Charitable Trusts and Greenpeace (2016) Statement to the Western and Central Pacific Fisheries Commission. 12th Regular Session of the Northern Committee, Fukuoka, 29 August-2 September 2016.

https://www.wcpfc.int/system/files/Joint\%20statement\%20from $\% 20$ the $\% 20$ Pew $\% 20$ Charitable\%20Trusts\%20and\%20Greenpeace\%20to\%20NC12.pdf

[5] WCPFC (2000) Convention on the Conservation and Management of Highly Migratory Fish Stocks in the Western and Central Pacific Ocean.

https://www.wcpfc.int/doc/convention-conservation-and-management-highly-migr atory-fish-stocks-western-and-central-pacific 
[6] Japan Fishery Agency (JFA) (2016) Stock Status and Management of Pacific Bluefin Tuna.

http://www.jfa.maff.go.jp/j/tuna/maguro_gyogyou/attach/pdf/bluefinkanri-1.pdf

[7] NOAA (2015) Pacific Bluefin Tuna (Thunnus orientalis). https://swfsc.noaa.gov/FRD-PacificBluefinTuna/

[8] WCPFC (2016) Reference Document for Review of CMM 2015-04 (Pacific Bluefin Tuna).

https://www.wcpfc.int/system/files/WCPFC13-2016-19\%20\%5BReference\%20docu ment\%20for\%20review\%20of\%20CMM\%202015-04\%20(PBF)\%5D.pdf

[9] Papastavrou, V. (1996) Sustainable Use of Whales: Whaling or Whale Watching? In: Taylor, V.J. and Dunstoneed, N., Ed., The Exploitation of Mammal Populations, Chapman \& Hall, London. https://doi.org/10.1007/978-94-009-1525-1_8

[10] Sekiyama, T. (2014) Coordination, Compromise, and Change: A Case of US-Japan Conflict over Commercial Whaling. International Relations and Diplomacy, 2, 310 322.

[11] Blanco, M., Sotelo, C.G., Chapela, M.J. and Pérez-Martín, R.I. (2007) Towards Sustainable and Efficient Use of Fishery Resources: Present and Future Trends. Trends in Food Science \& Technology, 18, 29-36. https://doi.org/10.1016/j.tifs.2006.07.015

\section{Scientific Research Publishing}

Submit or recommend next manuscript to SCIRP and we will provide best service for you:

Accepting pre-submission inquiries through Email, Facebook, LinkedIn, Twitter, etc. A wide selection of journals (inclusive of 9 subjects, more than 200 journals)

Providing 24-hour high-quality service

User-friendly online submission system

Fair and swift peer-review system

Efficient typesetting and proofreading procedure

Display of the result of downloads and visits, as well as the number of cited articles

Maximum dissemination of your research work

Submit your manuscript at: http://papersubmission.scirp.org/

Or contact jep@scirp.org 